\title{
Publicidade e interesse público: noções articuladas em instância normativa do Governo Federal do Brasil
}

Advertising and public interest: articulated notions in Brazil's Federal Government

\section{- Patrícia Gonçalves Saldanha}

Professora Associada da Universidade Federal Fluminense do curso de Publicidade e Propaganda e do quadro permanente do PPGMC/LaPA (Laboratório de Pesquisa Aplicada), coordenadora do Laccops e membro-fundador do Inpecc (Instituto Nacional de Pesquisa em Comunicação Comunitária), possui mestrado em Comunicação e doutorado em Comunicação e Cultura, ambos pela Universidade Federal do Rio de Janeiro.

E-mail: patsaldanhappgmc@gmail.com

\section{Marcelo Rodrigo de Avelar Bastos Alves}

Doutorando do Programa de Pós-Graduação Stricto Sensu em Informação e Comunicação em Saúde (PPGICS) do Instituto de Comunicação e Informação Científica e Tecnológica em Saúde (Icict) da Fundação Oswaldo Cruz (Fiocruz), bolsista Capes com graduação em Comunicação Social, habilitação em Publicidade e Propaganda, especialização em Gestão de Marketing, MBA em Gestão de Negócios e mestrado em Informação e Comunicação em Saúde.

E-mail: mavelaralves@gmail.com

Recebido em 31 de janeiro de 2017. Aprovado em 19 de abril de 2017.

\section{Resumo}

No Brasil, além do papel legislativo e judiciário, o Estado, em suas dimensões constitutiva e organizativa da sociedade, aciona elementos de natureza e intenção comunicacional centralmente por meio do poder executivo federal. A publicidade, tradicionalmente associada às práticas mercadológicas de iniciativa privada, é por ele desenvolvida dentro de dinâmicas e contextos próprios da esfera pública. No decorrer da revisão bibliográfica aliada ao estudo documental de material normativo, da Secom (website) enquanto corpus empírico, verificou-se como se articulam as noções de "publicidade" e "interesse público", evidenciando-se ausências, aproximações e tensões.

Palavras-chave: Publicidade. Interesse público. Comunicação. 


\section{Abstract}

Besides the legislative and judicial role, the Brazilian State, essentially through the federal executive power, triggers elements of nature and communicational purpose in its constitutive and organizational dimensions of society. Advertising, traditionally associated with commercial practices of private initiative, it is developed by it within the dynamics and contexts proper to the public sphere. In the course of the bibliographic review allied to the documentary study of normative material, Secom (website) as an empirical corpus, evidenced the articulations on the notions of "advertising" and "public interest', highlighting absences, approximations and tensions.

Keywords: Advertising. Public interest. Communication.

\section{Introdução}

A publicidade está associada às dimensões econômica e mercadológica, não somente pela natureza e por propósitos de sua prática profissional, mas também pelo lugar ocupado no contexto do capitalismo e sua visibilidade na promoção de marcas e produtos na mídia de massa e nos centros urbanos. Entretanto, se nos permitirmos um olhar mais abrangente, atento, crítico e sensível, ela também poderá ser localizada e entendida em outras dimensões. Nessa perspectiva, a publicidade extrapola sua existência instrumental ${ }^{1}-$ em última instância na promoção e divulgação das marcas de produtos e serviços - para se constituir como produto cultural e expressão social atravessada por política, religião, educação, saúde, entre outras perspectivas possíveis. Contemporaneamente, em um novo contexto epistemológico, tecnológico e geopolítico, é possível notar a emergência de uma concepção que se sobrepõe ao entendimento técnico a respeito da comunicação publicitária que, notoriamente, está em transformação. Elementos próprios da publicidade, como natureza, valores, práticas e conteúdos, estão sendo tensionados perante aspectos como a revisão das figuras do emissor e do receptor, o entendimento da identidade fragmentária dos sujeitos, da multiplicidade e complexidade das chamadas novas mídias² e, além disso, do novo espaço-tempo que permite o alcance em escala global articulado com realidades locais. Etimologicamente, publicidade deriva do latim publicus e designava "a qualidade do que é público [...], o ato de [...] de tornar público um fato, uma ideia"

1 Segundo Araújo (2001, p. 121), "a comunicação [...] entendida como um processo de transmissão de uma mensagem por uma fonte de informação, através de um canal, a um destinatário".

2 Incluindo tecnologias e dispositivos móveis diversos como smartphones e tablets.

$32 \frac{\text { Comunicação \& Inovação, PPGCOM/USCS }}{\text { v. 18, n. } 37 \text { (31-47) maio-ago } 2017}$ 
(SANT'ANNA; ROCHA JUNIOR; GARCIA, 2015, p. 67), foi assumida e desenvolvida fundamentalmente na iniciativa privada e, num segundo momento, foi legitimada pela legislação no cenário brasileiro. Nota-se, entretanto, que atualmente vem sendo apropriada pela sociedade civil organizada e pela esfera pública que a reconfiguram - não sem disputas e contradições.

Se entendermos que a publicidade tem sua existência no mundo social e que esse mundo se organiza dentro da lógica dos chamados "estados nacionais modernos", é fundamental pensarmos, assim, como ocorre a relação entre Estado e publicidade; sobretudo, adiante da possibilidade de a entendermos não como um ente apartado da sociedade, mas dela e nela constituído. O que se busca colocar aqui é que a publicidade não é uma abstração fora do espaço-tempo, mas possui uma existência concreta inserida social e historicamente em dada sociedade e lugar, os quais existem dentro de uma estrutura e organização social realizada na figura do Estado que tem sua existência materializada em instituições e procedimentos. Reconhecendo o governo como expressão do Estado, verifica-se que ele (governo) aciona políticas, estratégias e ações comunicacionais entre o Estado e a sociedade que o constitui. No Brasil, república federativa, o Poder Executivo Federal assume centralmente o governo do Estado em atuação nacional norteadora e estruturante que é articulada com as unidades da federação - estados e distrito. No que diz respeito às práticas publicitárias no território nacional, há uma regulação específica no âmbito do legislativo Lei $\mathrm{n}^{\circ}$ 4.680/1965, Decreto $\mathrm{n}^{\circ}$ 57.690/1966 e Decreto ${ }^{\circ}$ 4.563/2002 (BRASIL, 1965; 1966; 2003) - além de normatizações de naturezas diversas acionadas em temáticas e circunscrições próprias como no Código de Defesa do Consumidor, no Código Brasileiro de Autorregulamentação Publicitária e nas resoluções da Agência Nacional de Vigilância Sanitária. No entanto, a regulação específica das práticas publicitárias realizadas pelo próprio governo - o Estado recortado como o Poder Executivo Federal - é feita especificamente pela Secretaria Especial de Comunicação Social da Casa Civil da Presidência da República (Secom) por meio de instruções normativas com base na prerrogativa estabelecida na legislação (Id., 1979).

Nesse contexto, a comunicação publicitária em reconfiguração na contemporaneidade e o Estado como realizador de campanhas comunicacionais nacionais estratégicas que podem balizar outras e integrar políticas públicas - merecem atenção em sua potencial ou efetiva articulação, sobretudo, naquilo que é razão de existência do Estado, o bem público. Bem público esse que, nesse espaço, será angulado pela noção de interesse público, não somente como resultante do conjunto dos interesses que os indivíduos possuem, mas pela qualificação do interesse segundo o princípio da dignidade da pessoa humana (JUSTEN FILHO, 2016). Sabendo-se então que o arcabouço normativo materializado 
pelas instruções normativas publicadas pela Secom são produtos de construções sociais dentro de determinados contextos e interesses e, assim, propõe-se examinar a articulação entre as noções de publicidade e interesse público evocadas nas normativas. Objetivamente, identificar as noções de publicidade e de interesse público mobilizadas para entender sua articulação conceitual na instância normativa específica máxima do Poder Executivo Federal, a Secom.

Para tanto, conduziu-se revisão bibliográfica para a fundamentação teórica relativa aos conceitos de publicidade e interesse público. Posteriormente, em pesquisa documental e literatura, delineou-se o arcabouço normativo da comunicação publicitária do Poder Executivo Federal caracterizando organizacionalmente a Secom e se constituindo o corpus empírico a partir dos termos "publicidade" e "interesse público". Esse corpus foi então analisado à luz da teoria no intuito de identificar as noções atinentes aos dois termos de interesse, bem como problematizar sua articulação no contexto da comunicação governamental - sem perder de vista a interface com a sociedade civil e seus interesses.

A premissa aqui assumida é de que "termo", "definição", "conceito" e "noção" não se constituem como sinônimos ou equivalentes, ainda que estejam em íntima relação. Por "termo", entendemos a nomenclatura que designa e nomeia algo, como é o caso de publicidade e interesse público. O significado ou o sentido atribuído aos termos é variado e variável, construído na relação entre os interlocutores dentro de um contexto e repertório, refletindo e expressando de forma mais ou menos explícita um "conceito" - ideias, conhecimentos e concepções, teóricas ou não, a respeito de algo em sua constituição, natureza, caracterização e dinâmica de existência. Essas abstrações - os conceitos - são expressas de forma organizada e abrangente em enunciado que permite suficiente e relativa precisa compreensão sobre o algo a que se refere - trata-se aqui da "definição". Finalmente, por "noção" acreditamos poder pensá-la a partir de "conceito", porém the permitindo maior fluidez e abrangência de sentidos com limites conceituais mais difusos. Se o "conceito" traz uma pretensão totalizante e de circunscrição relativamente precisa, a "noção" se constitui como um conjunto de ideias mais ou menos fragmentadas, essenciais, difusas e articuladas. Menos que uma hierarquia valorativa, o que se coloca aqui é o entendimento de que se prestam a usos distintos.

\section{Publicidade e interesse público: noções e conceitos}

Diferentemente dos países de matriz anglo-saxã, nos quais a publicidade e a propaganda são terminologicamente bem diferenciadas - advertising e propaganda, respectivamente - no Brasil, os termos se confundem; seja na normatização governamental ou 
autoaplicada, seja no uso cotidiano leigo ou profissional, diferenciando-se, em alguma medida, na literatura científica. Há ainda um conjunto de termos correlacionados que orbitam e permeiam a discussão, como marketing e promoção, além de outros que são imbuídos de um status publicitário - pelo mercado e pela academia - como eventos, cidades, patrocínios, design e mídias sociais.

Uma sistematização realizada por Souza (2014) evidencia a diversidade das abordagens e entendimentos por autores brasileiros centrais (Quadro 1):

\begin{tabular}{|c|c|c|}
\hline Autor & $\begin{array}{l}\text { Abordagem Persuasiva/ } \\
\text { Mercadológica }\end{array}$ & $\begin{array}{l}\text { Abordagens outras: divulgação de ideias, } \\
\text { pessoas ou (até) mesmo produtos e empresas }\end{array}$ \\
\hline FILHO & Publicidade ou Propaganda & - \\
\hline PIEDRAS & Publicidade & Propaganda \\
\hline LUPPETI* & Propaganda & Publicidade \\
\hline PINHO & Publicidade & Propaganda \\
\hline SANTOS & Publicidade & Propaganda \\
\hline CASAQUI & Publicidade & $\begin{array}{l}\text { Propaganda (mas também englobando o que se faz como } \\
\text { Publicidade) }\end{array}$ \\
\hline
\end{tabular}

Quadro 1. Definições de publicidade e propaganda

Fonte: Souza (2014).

Isso não quer dizer, contudo, que não haja sentidos preferenciais, ainda que contextuais, ou esforços teóricos no intuito de demarcações conceituais. Sem nos remetermos aqui a uma reconstituição histórica ou etimológica do termo "publicidade", recuperamos os trabalhos de Gomes (2001) e Saldanha (2015), que pontuam o recente reconhecimento por parte da comunidade acadêmica da pertinência em se pensar conceitos e definições em suas aproximações e distanciamentos com a propaganda. Sobretudo, se consideramos haver uma mudança do aspecto tecnicista e normativo para uma abordagem teórica dentro de um novo contexto geopolítico e tecnológico.

Em que se pese a abordagem etimológica e a verificação pragmática dos usos, há uma vertente teórica nos estudos da comunicação publicitária que adota a perspectiva trabalhada por Santos e coloca objetivamente nos seguintes termos:

[publicidade] é todo processo de planejamento, criação, produção, veiculação e avaliação de anúncios pagos e assinados por organizações especificas (públicas, privadas ou do terceiro 
setor). Nessa acepção, as mensagens têm a finalidade de predispor o receptor a praticar uma ação específica (por exemplo, comprar um produto, abrir conta em um determinado banco, reciclar embalagens etc.). Essa ação tem localização no tempo e no espaço, podendo ser quantificada. (SANTOS, 2005, p. 17, grifos no original)

Apesar de Santos não vincular a publicidade a um caráter exclusivamente comercial, como é comum, essa perspectiva é entendida aqui como pertinente, uma vez que retoma o argumento etimológico trabalhado por Sant'Anna, Rocha Junior e Garcia (2015) e é coerente com o entendimento de grupos de legitimidade estratégicos - como a Associação Brasileira de Agências de Publicidade (Abap) - mas deve ser ponderada perante as problematizações e contribuições trazidas por Piedras (2009), Casaqui (2011) e por um grupo de pesquisadores em sua produção reunida no livro Ciberpublicidade: discurso, experiência e consumo na cultura transmidiática (ATEM; OLIVEIRA; AZEVEDO, 2014). Respectiva e essencialmente, pode-se sumarizar essas contribuições como: (1) a abordagem da publicidade a partir dos estudos culturais em uma visada crítica, autorreflexiva, multiperspectiva e multidimensional que reconheça a complexidade desse objeto multifacetado em sua articulação dinâmica com o mundo social; (2) o entendimento do processo publicitário dentro de uma teoria da publicização; e (3) a reconfiguração conceitual da publicidade a partir da própria prática publicitária reinterpretada em um novo contexto de dinâmicas e experiências na sociedade contemporânea.

Não obstante, parece-nos propício considerar o trabalho de Patrícia Saldanha ${ }^{3}$ que não só retoma a tipologia de Pinho (1990), que mais tarde será considerada pela Secom, mas sugere uma nova configuração da comunicação publicitária mais dialógica como a publicidade social. Trata-se de uma compreensão fundada em valores e participação social que permeia todo o processo de desenvolvimento publicitário numa proposta emancipatória e contra-hegemônica. Ela se articula com a publicidade de utilidade pública (PUP) à medida que envolve a mobilização do cidadão em um contexto político e social, mas possui notado distanciamento, já que a PUP, na acepção mais difundida, é integrada à comunicação governamental e assume uma perspectiva instrumental para adoção de comportamentos que tragam "benefícios tangíveis" e aumentem a qualidade de vida (COSTA, 2006).

A noção de interesse público emerge nesse cenário e poderia ser acionada em uma perspectiva filosófica ou jurídica, mas no escopo delimitado nos valemos da discussão dentro do contexto da comunicação e de uma rubrica conceitual denominada comunicação de interesse público (CIP), conforme proposto por Costa (2006). Apesar de questionamentos

3 SALDANHA, P. Publicidade social: um eixo alternativo para a publicidade mercadológica, pela via do consumo consciente e da apropriação das tecnologias móveis. No prelo. 
sobre o paradigma comunicacional no qual se funda, essa comunicação envolveria em sua dimensão de interesse público a noção de obtenção de benefícios concretos por sociedade e cidadão - visão de endossada por Brandão (2009) - e a ideia de que as ações de CIP não poderiam ser isoladas, mas fariam sentido dentro de um contexto maior de coerência na realização das ações entre si. Legítimo seria entender que esse interesse público não estaria então circunscrito ao âmbito governamental, nem tampouco estatal: a CIP poderia ser realizada no terceiro setor e também no setor privado. "A publicidade, tão experiente em tratar seus públicos como consumidores, também pode passar a tratá-los como cidadãos, sem que uma classificação se contraponha à outra" (FORMIGA SOBRINHO, 2012, p. 217). E até mesmo admitir a interpenetração público-privado com a negociação entre os atores em uma democracia consolidada, conforme o conceito de "comunicação pública" de Matos (1999).

Entretanto, seja acionado em CIP ou PUP, não podemos evitar problematizar que, sob o termo interesse público, há diferentes sentidos possíveis que consideram desde uma comunicação funcionalista verticalizada hegemônica que pressupõe o que é de interesse da população (ou da maioria) e prescreve comportamentos a serem adotados até uma comunicação dialógica emancipadora horizontalizada que mobiliza os sujeitos como atores sociais e políticos que, nessa vertente interativa, pactuam com a publicidade social, ainda que o conceito não seja oficialmente reconhecido pela Secom - como será visto mais à frente. Nesse diapasão, levantam-se alguns questionamentos: De onde parte a comunicação e qual a concepção de comunicação assumida? Quem estabelece e como se estabelece o que é de fato "interesse público"? Essas são questões que não podem ser desconsideradas, sobretudo, se entendermos que a supremacia do interesse público como interesse da maioria - pode implicar contradições na observância dos direitos fundamentais e humanos daqueles que não estão ali representados.

\section{Do marco teórico-metodológico: universo empírico e procedimentos}

Este estudo, além da revisão bibliográfica empreendida para fundamentação teórica, funda-se na pesquisa documental como entendida por Cellard (2012) e Sá-Silva, Almeida e Guindani (2009). Trata-se de identificação, coleta e sistematização de materiais de natureza diversificada - como o website da Secom - que não receberam tratamento analítico, superando assim a visão mais restrita sobre documentos como "registros textuais oficiais". O marco teórico maior no qual se desenvolve é o dos estudos culturais, como entendido por Du Gay et al. (2013) e Hall (2003) e apresentado por Ecosteguy (1999) e Johnson (1999), que reconhece a complexidade e multidimensionalidade das coisas e mobiliza abordagem multiperspectívica (KELLNER, 2001), acionando métodos e técnicas diversificadas de acordo com o objeto e problema de pesquisa - a identificação 
e problematização da articulação conceitual entre publicidade e interesse público na instância normativa do Poder Executivo Federal, entendendo-os como construções sociais em contextos específicos e com interesses implicados.

Nosso universo empírico é referenciado pela Secom que integra o Sistema de Comunicação de Governo do Poder Executivo Federal (Sicom), juntamente com todas as unidades da administração direta e indireta que atuam na gestão da comunicação social. Como órgão central, a Secom coordena, supervisiona e controla o Sicom, expedindo normas e instruções para as unidades mencionadas que deverão acatá-las sem, no entanto, implicar prejuízo na subordinação administrativa em seus respectivos órgãos de origem. A Secom é composta por cerca de 150 profissionais e é parte integrante da Presidência da República.

Cabe à Secom coordenar e aprovar os ajustes nas ações, metas, prazos e recursos dos planos anuais de comunicação (PAC) dos órgãos e também, especificamente, conforme o inciso $\mathrm{V}$ do artigo $8^{\circ}$ do Decreto $\mathrm{n}^{\mathrm{o}} 6.555 / 2008$, “coordenar o planejamento, o desenvolvimento e a execução das ações de propaganda e promoção institucionais e de propaganda de utilidade pública dos órgãos, das entidades e das sociedades" (BRASIL, 2008) que integram o Sicom. A ela cabe ainda a assistência direta e imediata da presidência da república, em especial no que diz respeito à elaboração e implantação da política de comunicação e divulgação social do governo, bem como a "coordenação, normatização, supervisão e controle da publicidade e de patrocínios dos órgãos e entidades da administração pública federal, direta e indireta, e de sociedades sob controle da União" (Ibid.). A Secom faz ainda a contratação e gestão de contratos diretamente com agências que servem à presidência ou órgãos sem estruturas de comunicação própria, funções e relações dispostas na Portaria n 100 (Id., 2012).

\section{Dos procedimentos e corpus}

Na pesquisa documental empreendida, a composição do corpus para análise se valeu da técnica de amostragem do tipo autogerada (MALHOTRA, 2006) na qual elementos que compõem o conjunto de interesse designam ou referenciam outros que também devem compô-lo. Partiu-se, então, dos documentos normativos - leis, decretos, instruções normativas, portarias e acordos - levantados no website da Secom por meio de sistema específico de busca que localiza "informações que apoiam o trabalho dos assessores de comunicação de instâncias governamentais, como manuais, legislação específica e indicação de boas práticas" (BRASIL, 2016). A partir da avaliação de pertinência e sua leitura, ampliou-se o corpus toda vez em que um dos materiais lidos fizesse menção a outro também entendido como relevante - que era assim incluído. Registre-se que o material 
mais recente - Portaria $n^{\circ}$ 98/2016 - serviu-nos como orientação sobre a validade e vigência dos demais na medida em que muitas vezes não há menções explícitas sobre revogações de anteriores; como é o caso exemplar da Instrução Normativa $n^{\circ} 05 / 2011$, para a qual não se localizou dispositivo revogatório (BRASIL, 2016; TOCANTINS, 2011). Não obstante, essa Portaria de 2016 ignora o Decreto $\mathrm{n}^{\circ}$ 7.379/2010, referindo-se ao Decreto $\mathrm{n}^{\mathrm{o}}$ 6.555/2008, seu antecessor e, nesse sentido, de necessária e mandatória atualização (BRASIL, 2008; 2010a). Assim e ao final, chegou-se a oito documentos conforme o Quadro 2, cuja análise teve como diretriz a identificação de termos, definições e conceitos de alusão direta ou indireta às noções de publicidade e interesse público.



Quadro 2. Corpus da pesquisa documental

Fonte: Brasil (2002; 2008; 2010a; 2010b; 2010c; 2014; 2016) e Tocantins (2011).

\section{Publicidade e interesse público: articulações nas instruções normativas}

Dentro do universo considerado, a propaganda se refere fundamentalmente à nomeação das agências prestadoras de serviços de publicidade, as "agências de propaganda"; na Portaria n 98/2016, há menção a "agenciador de propaganda" (BRASIL, 2016). Apenas na Lei $n^{0} 12.232 / 2010$ e na Instrução Normativa $n^{\circ} 04 / 2010$ foi verificado o termo "agência de publicidade" (Id., 2010b; 2010c). Na Lei no 12.232/2010, propaganda se refere implicitamente a material ou ação comunicacional (Id., 2010c). Por sua vez, publicidade assume duas grandes vertentes conceituais: a primeira, menos frequente, é aquela que coloca a publicidade como princípio constitucional da administração pública direta e indireta ${ }^{4}$ no sentido de visibilidade e notoriedade; a

4 Segundo o art. 37 da Constituição, "A administração pública direta e indireta de qualquer dos Poderes da União, dos Estados, do Distrito Federal e dos Municípios obedecerá aos princípios de legalidade, impessoalidade, moralidade, publicidade e eficiência" (BRASIL, 1988). 
segunda vertente se circunscreve na rubrica da comunicação social e assume sentidos mais específicos como espécie de comunicação, área de conhecimento, serviços profissionais, ações ou materiais publicitários com fins de divulgação (Id., 1988; 2010).

Dado o nosso interesse na dimensão conceitual, enfoca-se e se sumariza as definições presentes nos materiais, conforme adiante. O Manual de Procedimentos das Ações de Publicidade, aprovado pela Portaria n ${ }^{\circ}$ 98/2016, embora o mais atual, assume uma visada burocrático-jurídica e coloca que "constituem ações de publicidade, para fins deste Manual, os serviços integrantes do objeto dos contratos firmados pela Secom com agências de propaganda" (Id., 2016). Já a Lei nº 12.232/2010, embora traga um detalhamento, efetivamente não define publicidade, mas tipifica objetivos e, em certo sentido, etapas e atividades a ela pertinentes (Id., 2010c). Assim, o conceito existente é vago e orbita a noção de "conjunto de atividades dentro de objetivos de promoção, difusão e informação":

considera-se serviços de publicidade o conjunto de atividades realizadas integradamente que tenham por objetivo o estudo, o planejamento, a conceituação, a concepção, a criação, a execução interna, a intermediação e a supervisão da execução externa e a distribuição de publicidade aos veículos e demais meios de divulgação, com o objetivo de promover a venda de bens ou serviços de qualquer natureza, difundir ideias ou informar o público em geral (Id., 2010c)

De relevância ímpar dentro do nosso escopo de interesses está a Instrução Normativa $n^{\circ}$ 07/2014, já que "a publicidade dos órgãos e entidades do Poder Executivo Federal é regulada pelas disposições [dessa] Instrução Normativa”. Nela, também não há definição da publicidade propriamente dita, mas o reconhecimento de uma tipologia "espécies de publicidade" nos termos da norma - composta por PUP, publicidade mercadológica, publicidade institucional e publicidade legal. De forma a orientar toda a ação publicitária, determina-se: a observância do princípio da impessoalidade e o necessário caráter educativo, informativo ou de orientação social; a busca da compreensão pelo cidadão das políticas públicas, responsabilidades dos governos, transparência da gestão; e o estímulo ao controle social, dentre outros aspectos. Coloca-se também economicidade, tecnicidade, valorização da desconcentração e respeito à regionalização nos investimentos em veiculação midiática (Id., 2014).

A publicidade legal se refere essencialmente à noção de visibilidade dentro do atendimento a prescrições legais e ao princípio constitucional da administração pública fugindo, inclusive, da necessidade de aprovação pela Secom. A publicidade mercadológica possui, como na iniciativa privada, foco na promoção de produtos - bens ou serviços- 
no mercado e diz respeito essencialmente às empresas públicas e de economia mista e, se "não vinculada a políticas públicas do Poder Executivo Federal" (Ibid., 2014) também não são analisadas pela Secom. As outras duas espécies de publicidade parecem trazer as melhores evidências da aproximação entre publicidade e interesse público. Sobretudo quando pensadas conjuntamente com o conceito de comunicação pública presente na Instrução Normativa $n^{\circ}$ 05/2011 (TOCANTINS, 2011). Porém, antes de nos debruçarmos sobre esse ponto central do trabalho, cumpre trazer definições úteis, associadas e complementares, da Instrução Normativa $n^{0} 4 / 2010$, que nos ajudam a pensar o conceito de publicidade existente na instância normativa do Poder Executivo Federal (BRASIL, 2010b). São eles peça e material publicitário, ação publicitária e serviço de publicidade que, essencial e respectivamente, dizem respeito aos elementos produzidos constituintes da comunicação publicitária, ao conjunto de serviços da agência e fornecedores referentes à peça e material publicitário e ao conjunto de atividades profissionais publicitárias muito similares às práticas de mercado.

Entendendo que a maior centralidade na articulação das noções de "publicidade" e "interesse público" parece se expressar na PUP, adotou-se como estratégia analítica o enfoque nas modificações que ocorreram nas suas definições ao longo do tempo considerando, no contexto normativo, a comunicação pública como referência mais abrangente conceitualmente -

ação de comunicação que se realiza por meio da articulação de diferentes ferramentas capazes de criar, integrar, interagir e fomentar conteúdos de comunicação destinados a garantir o exercício da cidadania, o acesso aos serviços e informações de interesse público, a transparência das políticas públicas e a prestação de contas do Poder Executivo Federal (TOCANTINS, 2011)

- e a publicidade institucional como correlação mais direta - publicidade que

destina-se a posicionar e fortalecer as instituições, prestar contas de atos, obras, programas, serviços, metas e resultados das ações do Poder Executivo Federal, com o objetivo de atender ao princípio da publicidade e de estimular a participação da sociedade no debate, no controle e na formulação de políticas públicas e de promover o Brasil no exterior [...] [devendo] [...] priorizar a divulgação de ações e resultados concretos, em detrimento a promessas ou realizações ainda não implementadas; [...] ressaltar [...] os benefícios diretos e indiretos das ações do Poder Executivo Federal para a sociedade; [...] privilegiar o uso de pessoas, cenas e casos reais na publicidade institucional de prestação de contas (BRASIL, 2014). 
A sistematização de mudanças a seguir (Quadro 3) organiza os entendimentos sobre PUP existentes considerando fonte material, definição explícita e caracterização explícita ou implícita nos materiais.

\begin{tabular}{|c|c|}
\hline Fonte & Acordo Secom CENP/2002 \\
\hline Definição & $\begin{array}{l}\text { "a que tem como objetivo informar, orientar, avisar, prevenir ou alertar a população ou } \\
\text { segmento da população para adotar comportamentos que lhe tragam benefícios sociais reais, } \\
\text { visando melhorar a sua qualidade de vida" (BRASIL, 2002). }\end{array}$ \\
\hline Caracterização & $\begin{array}{l}\text { Deve "vincular-se a objetivos sociais de inquestionável interesse público, sempre assumindo } \\
\text { caráter educativo, informativo ou de orientação social; }[\ldots] \text { conter sempre um comando, que } \\
\text { oriente a população a adotar um comportamento, e uma promessa de benefício, individual } \\
\text { ou coletivo, que possa vir a ser cobrado pelo cidadão; }[\ldots] \text { não pode: }[\ldots] \text { conter elementos } \\
\text { próprios das Publicidades Institucional ou Mercadológica; }[\ldots] \text { ter sua mensagem social } \\
\text { encoberta por qualquer outro conceito" (BRASIL, 2002). }\end{array}$ \\
\hline Fonte & Instrução Normativa n 05/2011 \\
\hline Defînição & $\begin{array}{l}\text { "a que se destina a divulgar direitos, produtos e serviços colocados à disposição dos cidadãos, } \\
\text { com o objetivo de informar, educar, orientar, mobilizar, prevenir ou alertar a população para } \\
\text { adotar comportamentos que lhe tragam benefícios individuais ou coletivos e que melhorem a } \\
\text { sua qualidade de vida" (TOCANTINS, 2011). }\end{array}$ \\
\hline Caracterização & Não há. \\
\hline Fonte & Instrução Normativa n 07/2014 \\
\hline Defînição & $\begin{array}{l}\text { "destina-se a divulgar temas de interesse social e apresenta comando de ação objetivo, claro } \\
\text { e de fácil entendimento, com o objetivo de informar, educar, orientar, mobilizar, prevenir ou } \\
\text { alertar a população para a adoção de comportamentos que gerem benefícios individuais e/ou } \\
\text { coletivos" (BRASIL, 2014). }\end{array}$ \\
\hline Caracterização & Não há específica para PUP. \\
\hline
\end{tabular}

Quadiro 3. Transformações da definição de publicidade de utilidade pública

Fonte: Elaboração dos autores.

A definição de PUP tem como ponto de partida o "Acordo entre o Governo Federal e o Mercado Publicitário sobre Publicidade de Utilidade Pública" firmado em

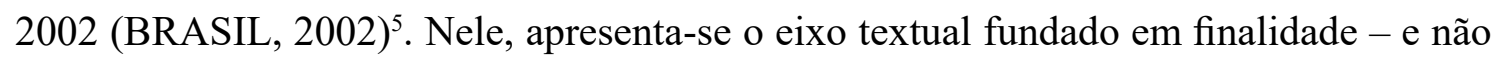
em natureza e caracterização - que perdura até o momento atual. Envolve objetivos comunicacionais visando à mudança comportamental da população com "benefícios sociais reais" para melhor qualidade de vida. Em 2011, a Instrução Normativa $n^{0} 05$ se propõe a uma conceituação também orientada para finalidade, incluindo especificamente a divulgação de "direitos, produtos e serviços colocados à disposição dos cidadãos" e substituindo os "benefícios sociais reais" por "benefícios individuais ou coletivos". Finalmente, em 2014, a Instrução Normativa n 07 atualiza a definição com "temas de interesse social" no lugar de "direitos, serviços e produtos", com a inserção de "comando de ação" e supressão de "melhoria de qualidade de vida" (Id., 2014). A PUP apresenta, assim, definições

5 O acordo foi assinado por entidades representativas, a Secretaria de Estado de Comunicação de Governo da Presidência da República e o Conselho Executivo das Normas-Padrão. 
que não expressam exatamente conceitos - no sentido de entendimento da natureza, caracterização e finalidade de algo, ou seja, o que esse algo é, como ele é e sua dinâmica de existência. Parece mais apropriado para nós entender que os materiais normativos trazem elementos que permitem a construção de uma noção sobre a PUP, algo mais difuso e abrangente que um conceito, mas que orienta um entendimento consistente o suficiente para diferenciar o que lhe é atinente do que não o é.

\section{Uma análise à guisa de conclusão}

A partir do conjunto de verificações e análises realizadas, entendemos não haver propriamente um conceito de publicidade na instância normativa do Poder Executivo Federal, mas elementos e aspectos mais ou menos diretos e explícitos que permitem reconhecer a publicidade não por sua natureza per se, mas por ser de autoria de agências de propaganda. Colocada em perspectiva finalística - objetivos e destinação - evidencia um caráter prescritivo - ainda que usando termos como educar e informar - e uma influência behaviorista - com a sempre presente intenção de mudar comportamentos e com a determinação de uso de um "comando de ação". Dadas as características próprias dos textos do gênero normativo, não se angulou os esforços desenvolvidos para encontrar teorizações ou conceituações problematizadas, mas para identificar delimitações técnico-jurídicas de publicidade que fossem claras e explícitas. E, ainda que em sua ausência, elementos que subsidiassem a compreensão do termo e do que o mobiliza e por ele é mobilizado.

Aqui, a noção de interesse público se articula de forma mais relevante ao se apresentar, não como interesse do público (a população), mas como utilidade pública, interesse comum ou social e benefícios individuais ou coletivos. Sem perder de vista a possibilidade da visada da ciência política nessa compreensão, cabe a ponderação sobre o consistente levantamento dos interesses da população ou sua presunção: Como o Poder Executivo Federal identifica e estabelece o que é de interesse público? No material analisado não há definição do que é interesse público, nem sua caracterização explícita ou sua vinculação com termos correlatos. Acima de tudo, a noção possível de interesse público surge difusamente associada às ideias de benefícios, melhoria da qualidade de vida e, centralmente, de "utilidade pública" vinculada quase que exclusivamente à espécie publicitária PUP. Em sua caracterização, sinaliza também preocupação com a dimensão de cidadania e política - cidadão, orientação social, políticas públicas, responsabilidades dos governos etc. - ao mesmo tempo que parece colocar os sujeitos numa posição de passividade - o cidadão é que deve ser informado, educado, orientado, mobilizado, prevenido ou alertado, inclusive, com um claro "comando de ação". 
Há, entretanto, uma contraposição no artigo $6^{\circ}$ da Instrução Normativa $n^{\circ}$ 07/2014, que coloca o estímulo ao "controle social" para toda publicidade a ser desenvolvida, e no artigo $3^{\circ}$ da mesma instrução ao conceituar a publicidade institucional, prescrevendo o estímulo à "participação da sociedade no debate, no controle e na formulação de políticas públicas" (BRASIL, 2014). Nesses dois casos, os sujeitos são reconhecidos como atores, inclusive como atores sociais e políticos.

O quadro delineado ao final é que o Estado, por meio dos três poderes e em suas especificidades, dispõe e disciplina as práticas publicitárias no território nacional, mas o Poder Executivo Federal, em sua centralidade organizativa no Brasil, assume relevância ao ser, ele próprio e por seus órgãos e entidades, destacado demandante e contratante de serviços publicitários de comunicação estratégica estruturante em âmbito nacional. Os procedimentos implicados a partir disso estão normatizados em um conjunto de leis, decretos, portarias e dispositivos diversos que são observados, reunidos e organizados em práticas e orientações desenvolvidas pela Secom para todos os órgãos e entidades do Poder Executivo Federal. Nessa instância normativa máxima desse poder, a publicidade não apresenta um conceito claramente delimitado em uma definição, mas elementos e evidências que permitem a construção de uma noção mais ou menos precisa daquilo que ela é e do que não é. Essa noção, como toda noção, é difusa e delineia o entendimento de publicidade como ação e serviço de comunicação com processos e características fortemente vinculados à ideia de "resultado de atividades e conhecimentos" desenvolvidos por uma agência de propaganda. Embora haja evidências de uma preocupação em se colocar o sujeito de forma ativa como cidadão, como ator social e político, ainda emerge uma concepção de publicidade em perspectiva instrumental, linear, prescritiva e behaviorista.

Por sua vez, o interesse público, nessa mesma instância normativa, não possui conceito ou definição, mas somente pistas do entendimento que parece haver sobre o termo. Seu sentido e significado é tratado como se já estivesse dado, fosse unívoco e notório. As percepções mais fortes são de que o interesse público se vincula a benefícios e qualidade de vida, sugerindo mais tenuemente que tais benefícios, individuais ou coletivos, seriam de orientação social e política. Esse interesse público se articula com a publicidade de modo claro em publicidade institucional e PUP, com destaque para esta última, funcionando como um qualificador desses tipos de publicidade. De forma explícita, é a PUP que mobiliza a noção de interesse público ao tomá-lo, em alguma medida, dentro do termo "utilidade pública". Nesse sentido, as noções publicidade e interesse público são articuladas e tensionadas em visadas convergentes, divergentes e contraditórias: de um lado, a presunção do interesse público e a ausência de mecanismos para sua verificação; de outro, sua vinculação às noções de participação e controle social, 
bem como o entendimento do sujeito como ator social e político; de um lado, a publicidade instrumental que prescreve comportamentos a serem adotados; de outro, as diretrizes que colocam em cena a cidadania, a política, o social e enfraquece a figura de receptor na comunicação. Contradições e aproximações que colocam em cena um complexo arranjo de elementos que mobilizam desde o sentido original com o termo publicus até uma concepção singular como publicidade social.

\section{Referências}

ARAÚJO, C. A. A pesquisa norte-americana. In: HOHLFELDT, A.; MARTINO, L. C.; FRANÇA, V. V. (Orgs.). Teorias da comunicação: conceitos, escolas e tendências. Petrópolis: Vozes, 2001.

ATEM, G.; OLIVEIRA, T.; AZEVEDO, S. (Orgs.). Ciberpublicidade: discurso, experiência e consumo na cultura transmidiática. Rio de Janeiro: E-papers, 2014.

BRANDÃO. E. P. Conceito de comunicação pública. In: DUARTE, J. (Org.). Comunicação pública: Estado, mercado, sociedade e interesse público. 2. ed. São Paulo: Atlas, 2009.

BRASIL. Acordo entre o Governo Federal e o Mercado Publicitário sobre Publicidade de Utilidade Pública. Brasília, DF: Secom, 2002.

Constituição da República Federativa do Brasil de 1988. Diário Oficial da União, Poder Executivo, Brasília, DF, 5 out. 1988. Seção 1, p. 1.

Decreto $\mathrm{n}^{\circ} 4.563$, de 31 de dezembro de 2002. Altera o Regulamento aprovado pelo Decreto $\mathrm{n}^{\mathrm{o}}$ 57.690, de 1 de fevereiro de 1966, para a execução da Lei ${ }^{\circ}$ 4.680, de 18 de junho de 1965 . Diário Oficial da União, Poder Executivo, Brasília, DF, 1 jan. 2003. Disponível em: <https://goo. gl/CI0Spb>. Acesso em: 13 jun. 2017.

Decreto $\mathrm{n}^{\circ}$ 6.555, de 8 de setembro de 2008. Dispõe sobre as ações de comunicação do Poder Executivo e dá outras providências. Diário Oficial da União, Poder Executivo, Brasília, DF, 9 set. 2008. Disponível em: <https://goo.gl/wcFzZl>. Acesso em: 21 jan. 2017.

. Decreto $\mathrm{n}^{\circ} 7.379$, de 1 de dezembro de 2010. Dá nova redação e acresce dispositivos ao Decreto $\mathrm{n}^{\circ}$ 6.555, de 8 de setembro de 2008, que dispõe sobre as ações de comunicação do Poder Executivo Federal e dá outras providências. Diário Oficial da União, Poder Executivo, Brasília, DF, 2 dez. 2010a.

Decreto $n^{\circ} 57.690$, de 1 de fevereiro de 1966. Aprova o Regulamento para a execução da Lei $n^{\circ}$ 4.680, de 18 de junho de de 1965. Diário Oficial da União, Poder Executivo, Brasília, DF, 10 fev. 1966. Disponível em: <https://goo.gl/qOHxNn>. Acesso em: 13 jun. 2017.

Instrução Normativa $n^{\circ} 4$, de 11 de setembro de 2010. Dispõe sobre o processo de contratação de Soluções de Tecnologia da Informação pelos órgãos integrantes do Sistema de Administração 
dos Recursos de Tecnologia da Informação - SISP do Poder Executivo Federal. Diário Oficial da União, Poder Executivo, Brasília, DF, 12 set. 2010b.

. Instrução Normativa n ${ }^{0} 7$, de 12 de setembro de 2014. Dispõe sobre os procedimentos a serem adotados pelos órgãos setoriais, seccionais e correlatos do Sistema de Pessoal Civil da Administração Pública Federal - Sipec para análise, autorização e liberação de recursos financeiros necessários ao pagamento de resíduos remuneratórios autorizados por meio de alvará judicial e dá outras providências. Diário Oficial da União, Brasília, DF, 16 set. 2014.

Lei $n^{\circ} 4.680$, de 18 de junho de 1965. Dispõe sobre o exercício da profissão de Publicitário e de Agenciador de Propaganda e dá outras providências. Diário Oficial da União, Poder Executivo, Brasília, DF, 21 jun. 1965. Disponível em: <https://goo.gl/9482Bu>. Acesso em: 13 jun. 2017.

Lei $n^{0}$ 6.650, de 23 de maio de 1979. Dispõe sobre a criação, na Presidência da República, da Secretaria de Comunicação Social, altera dispositivos do Decreto-lei no 200, de 25 de fevereiro de 1967, e dá outras providências. Diário Oficial da União, Poder Executivo, Brasília, DF, 24 maio 1979.

Lei $n^{\circ} 12.232$, de 29 de abril de 2010. Dispõe sobre as normas gerais para licitação e contratação pela administração pública de serviços de publicidade prestados por intermédio de agências de propaganda e dá outras providências. Diário Oficial da União, Poder Executivo, Brasília, DF, 30 abr. 2010c.

. Portaria $\mathrm{n}^{\circ}$ 98, de 9 de junho de 2016. Altera a Portaria ${ }^{\circ} 35$, de 1 de março de 2016, que estabelece orientações aos órgãos e entidades integrantes do Sistema de Pessoal Civil da Administração Federal - Sipec quanto aos requisitos e procedimentos a serem observados para a concessão de licença para tratar de interesses particulares, de que trata o art. 91 da Lei no 8.112, de 11 de dezembro de 1990, e dá outras providências. Diário Oficial da União, Poder Executivo, Brasília, DF, 10 jun. 2016

. Secretaria de Comunicação Social. Portaria $n^{\circ}$ 100, de 13 de agosto de 2012. Dispõe sobre as condições, atribuições e forma de atuação dos servidores da Secom na gestão de contratos firmados com agências de propaganda para prestação de serviços de publicidade e altera o Manual de Procedimento das Ações de Publicidade. Diário Oficial da União, Brasília, DF, 14 ago. 2012. Disponível em: <https://goo.gl/rYHH67>. Acesso em: 13 jun. 2017.

. Secretaria de Comunicação Social. Site Secom, 2016. Disponível em: <https://goo.gl/tMYQob>. Acesso em: 21 jan. 2017.

CASAQUI, V. Por uma teoria da publicização: transformações no processo publicitário. In: CONGRESSO BRASILEIRO DE CIÊNCIAS DA COMUNICAÇÃO, 34., 2011, Recife. Anais... Recife: Intercom, 2011. p. 1-15.

CELLARD, A. A análise documental. In: POUPART, J. et al. A pesquisa qualitativa: enfoques epistemológicos e metodológicos. 3. ed. Petrópolis: Vozes, 2012.

$46 \frac{\text { Comunicação \& Inovação, PPGCOM/USCS }}{\text { v. 18, n. } 37 \text { (31-47) maio-ago } 2017}$ 
COSTA, J. R. V. Comunicação de interesse público: ideias que movem pessoas e fazem um mundo melhor. São Paulo: Jaboticaba, 2006

DU GAY, P. et al. Doing cultural studies: the story of the Sony Walkman. 2. ed. London: Sage, 2013.

ESCOSTEGUY, A. C. D. Estudos culturais e recepção. Novos Olhares, São Paulo, v. 2, p. 44-49, 1999. Disponível em: <https://goo.gl/9RrnPH>. Acesso em: 20 jan. 2017.

FORMIGA SOBRINHO, A. B. A publicidade saudável na comunicação pública. Organicom, São Paulo, v. 9, p. 213-222, 2012.

GOMES, N. D. Publicidade ou propaganda? É isso aí! Revista Famecos, Porto Alegre, n. 16, p. 111-121, 2001.

HALL, S. Reflexões sobre o modelo de codificação/decodificação: uma entrevista com Stuart Hall. In: Da diáspora: identidades e mediações culturais. Belo Horizonte: UFMG, 2003. p. 353-386.

JOHNSON, R. O que é, afinal, estudos culturais? In: SILVA, T. T. (Org.) O que é, afinal, estudos culturais? Belo Horizonte: Autêntica, 1999.

JUSTEN FILHO, M. Curso de direito administrativo. 12. ed. São Paulo: Saraiva, 2016

KELLNER, D. A cultura da mídia. São Paulo: Edusc, 2001.

MALHOTRA, N. K. Pesquisa de marketing: uma orientação aplicada. 4. ed. Porto Alegre: Bookman, 2006.

MATOS, H. Comunicação pública, democracia e cidadania: o caso do legislativo. São Paulo: Faculdade Cásper Líbero, 1999.

PIEDRAS, E. Fluxo publicitário: anúncios, produtores e receptores. Porto Alegre: Sulina, 2009.

PINHO, J. B. Propaganda institucional: usos e funções da propaganda em relações públicas. São Paulo: Summus, 1990.

SALDANHA, P. Publicidade como ferramenta estratégica da propaganda infantojuvenil no Brasil: quem regula afinal? In: BARBALHO, A.; MARÔPO, L. (Orgs.). Infância, juventude e mídia: olhares luso-brasileiros. Fortaleza: EdUECE, 2015.

SANT’ANNA, A.; ROCHA JÚNIOR, I.; GARCIA, L. F. D. Propaganda: teoria, técnica e prática. 9. ed. São Paulo: Cengage Learning, 2015.

SÁ-SILVA, J. R.; ALMEIDA, C. D.; GUINDANI, J. F. Pesquisa documental: pistas teóricas e metodológicas. Revista Brasileira de História \& Ciências Sociais, São Leopoldo, v. 1, n. 1, p. 1-15, 2009.

SOUZA, A. Entre consumo e conceitos: apontamentos para uma jurisdição aos usos dos termos publicidade, propaganda e marketing no ambiente digital. In: CONGRESSO INTERNACIONAL EM COMUNICAÇÃO E CONSUMO, 4., 2014, São Paulo. Anais... São Paulo: ESPM, 2014. Disponível em: <https://goo.gl/8uQY9e>. Acesso em: 21 jan. 2017.

TOCANTINS (Estado). Instrução Normativa $n^{\circ}$ 5, de 24 de outubro de 2011. Regulamenta o processo judicial eletrônico - e-Proc/TJTO, no âmbito do Poder Judiciário do Estado do Tocantins e dá outras providências. Diário da Justiça Eletrônico, Palmas, 25 out. 2011. 